\title{
Diyabetli Hastalarda Psikolojik İnsülin Direnci Ölçeğinin Türkçeye Uyarlanması
}

\section{Turkish Adaptation of Psychological Insulin Resistance Scale in Diabetic Patients}

${ }^{1}$ Kevser IŞIK, ${ }^{2}$ Hilal YILDIRIM, ${ }^{2}$ Zeliha CENGIZZ

\section{ÖZET}

Amaç: Bu araştırma, diyabetli hastalarda psikolojik insülin direnci ölçeğinin Türkçeye uyarlanması amacıyla yapıldı. Gereç ve Yöntemler: Metodolojik türde yapılan araştırma için belirlenen minimum örneklem sayısı 180'di (orijinal ölçekte yer alan 18 madde sayısının 10 katı alınarak belirlendi). Araştırma toplam 201 diyabet hastası ile tamamlandı. Veri toplama aracı olarak diyabetli hastaları Tanıtıcı Anket Formu ve Psikolojik İnsülin Direnci Ölçeği kullanıldı. Bulgular: Psikolojik İnsülin Direnci Ölçeğinin faktör analizinde öz değeri 1'in üstünde olan 3 faktörlü (destekleyici, psiko-bilişsel ve fiziksel faktörler) 12 sorudan oluştuğu, toplam varyans değerinin \%60,4 olduğu belirlendi. Kaiser-Meyer-Olkin değeri 0,77, Bartlett's testi $\mathrm{X}^{2}=877,833, \mathrm{p}<0,001$ ve Cronbach alfa katsayısı 0,82 olarak hesaplandı. Sonuç: Yapılan geçerlik ve güvenirlik çalışması sonucunda ölçeğin Türk toplumuna uygun ve tip 2 diyabetli hastalarda psikolojik insülin direnci varlı̆̆ını değerlendirmede geçerli ve güvenilir bir ölçme aracı olduğu belirlendi. Ölçeğin özellikle klinikte çalışan hemşirelerin tip 2 diyabetli hastaları insülin tedavisine karşı psikolojik yönden değerlendirme firsatı sunmada yararlı olacağı düşünülebilir. Ölçeğin daha büyük örneklem grubu ile çalışılması önerilebilir.

Anahtar kelimeler: Tip 2 diyabet, psikolojik insülin direnci, hemşire, geçerlik, güvenirlik

\begin{abstract}
Aim: This study was carried out to Turkish Adaptation of Psychological Insulin Resistance Scale in Diabetic Patients Methods: The minimum number of samples determined for the research conducted in the methodological type is 180 (it was determined by taking 10 times the number of 18 items in the original scale). The study was completed with a total of 201 diabetic patients. Descriptive Questionnaire Form and Psychological Insulin Resistance Scale were used as data collection tools. Results: In the factor analysis of the Psychological Insulin Resistance Scale, it was determined that it consists of 12 questions with 3 factors (supporting, psycho-cognitive and physically factors) with an eigenvalue above 1, and the total variance value was $60.9 \%$. KMO (Kaiser-Meyer-Olkin) value was calculated as 0.77 , Bartlett's test $\mathrm{X}^{2}=877.833, \mathrm{p}<.001$ and Cronbach alpha coefficient 0.82 . Conclusion: As a result of the validity and reliability study, it was determineted that the scale is suitable for Turkish society and is a valid and reliable measurement tool for evaluating the presence of psychological insulin resistance in patients with type 2 diabetes. It is thought that especially nurses working in the clinic will be useful in providing the opportunity to evaluate patients psychologically against insulin therapy. It is recommended that the scale should be used to determine psychological insulin resistance in patients with type 2 diabetes and to study with a larger sample group.
\end{abstract}

Keywords: Type 2 diabetes, psychological insulin resistance, nurse, validity, reliability

Received / Geliş Tarihi: 19.01.2021, Accepted / Kabul Tarihi: 25.08.2021

1.Kahramanmaraş Sütçü İmam Üniversitesi, Sağlı Bilimleri Fakültesi, Halk Sağlığı Hemşireliği, Kahramanmaraş, TÜRKIYE

2.İnönü Üniversitesi, Hemşirelik Fakültesi, Malatya, Türkiye

*Address for Correspondence / YazışmaAdresi:

Kahramanmaraş Sütçü İmam Üniversitesi, Sağlık Bilimleri Fakültesi, Halk Sağlığı Hemşireliği, Kahramanmaraş, TÜRKIYE

Tel: +90 34430026 01/2604, E mail: kevser isik@hotmail.com

IŞIK K, YILDIRIM H, CENGIZZ Z. Diyabetli Hastalarda Psikolojik İnsülin Direnci Ölçeğinin Türkçeye Uyarlanması. TJFMPC, 2021;15(4): 726-733.

DOI: $10.21763 /$ tjfmpc.864093 


\section{GİRIŞ}

Diyabet hastalarına uygulanan insülin tedavisi hiperglisemiyi azaltarak optimal glisemik kontrol sağlayabilir. ${ }^{1}$ İnsülin tedavisinin uygulanmasına rağmen kötü glisemik kontrol, tip 2 diyabetli hastalarda yaygındır. Bu durumun en önemli nedenlerinden biri tip 2 diyabetli birçok hastanın insülin tedavisine isteksizlik duyması veya insülin tedavisinden korkmasıdır. ${ }^{2,3,4}$ Insülin tedavisinin bu olumsuz alg1sı "Psikolojik İnsülin Direnci" (PİD) olarak adlandırılır. ${ }^{2}$

Bir hastanın; hipoglisemik problemler, günlük yaşam aktivitelerinde kısıtlamalar ve kendi kendine enjeksiyon yapma konularında bilişsel zorluklar yaşadığ 1 psikolojik durum PID olarak adlandırılır. ${ }^{5,6} \mathrm{Bu}$ tanım, duygusal sıkıntı ve yoğun tıbbi tedaviye yönelik olumsuz tutumlar da dahil olmak üzere çeşitli faktörler nedeniyle insülin tedavisine başlamak için güçlü bir olumsuz tutumu tanımlayan bir terim olup tıbbi bir psikolojik tanı değildir. $^{7}$

Diyabetli hastalarda insülinin hedeflenen glisemik değerlere ulaşılmasında mevcut en güçlü ilaç olduğu gerçeği göz önüne alındığında, insülin tedavisine başlama veya uyumunun önemli bir klinik sorun olmayacağı varsayılabilir. ${ }^{8}$ PID prevalansının tip 2 diyabetli insülin kullanan hastaların yaklaşık üçte birinde görüldüğü bildirilmektedir. ${ }^{7,9,10}$ Diyabet hastalarının çoğunun, insülinin genel sağlık durumlarında olumlu bir fark yaratmayacağına inandıkları ifade edilmektedir. ${ }^{11}$ Diyabet hastalarının \%40'1 insülin tedavisinin iyi kan şekeri kontrolü elde edilmesine veya iyileşme süreçlerine yardımcı olduğuna inanmamaktadır. ${ }^{12}$ PID olan hastalar olumsuz benlik algısı yaşarlar. Ayrıca hastalar insülinle ilişkili yan etkiler, sosyal damgalanma ve gerekli yaşam tarzı uyumları konusunda endişe duyarlar. ${ }^{6,13} \mathrm{Bu}$ endişeler tedavide gecikmeye yol açar, glisemik kontrolü güçleştirebilir ve hastalık sürecini olumsuz etkileyerek, yaşam kalitesini azaltabilir. ${ }^{14}$ Son çalışmalar, tip 2 diyabetli hastalarda insülin tedavisinin reddedilme oranını \%20-70 aralığında olduğunu bildirmektedir. İnsülin tedavisini reddetme oranlarındaki farklılıkların; kültürel normlardan, bireysel sağlıkla ilgili inançlardan, psikososyal faktörlerden ve sağlık sistemlerinden kaynaklanabileceği düşünülmektedir. ${ }^{6,15,16}$ Ayrıca insülinin reddedilme oranlarının, yaşadığı bölgeye bakılmaksızın, düşük gelirli ve 1rksal azınlık gruplarında daha yüksek olduğu bildirilmiştir. Bu nedenle insülin tedavisinin reddedilme nedenlerinin araştırılması önemlidir. , $^{67,18}$

Hastanelerde diyabetli hastalarla en fazla zaman geçiren sağlık personeli hemşirelerdir. Diyabetin kontrol altına alınmasında insülin tedavisi büyük önem taşımaktadır. $\mathrm{Bu}$ nedenle doğru insülin uygulanması konusundaki var olan eğitim eksikliğinin giderilerek tedavinin daha etkin ve başarılı olmasında hemşirelere büyük görevler düşmektedir. ${ }^{19} \mathrm{Bu}$ nedenle hemşireler hastalarda insülin tedavisine karşı oluşan psikolojik engelleri tanımlayabilmelidir.

PİD ile ilgili yapılan çalışmaların sadece birkaçında geçerlik ve güvenirliği yapılmış psikometrik araçlar kullanılmışs,6,14, diğerleri ise onaylanmamış anketler veya görüşmeler yoluyla yapılmıştır. ${ }^{20-23}$ Insülin tedavisinin başlatılmasındaki psikolojik engelleri araştırmak için, Song ve arkadaşları tarafından 2016 yılında PİD Ölçeği geliştirilmiştir. PID, insülin kullanımı ile ilgili psiko-bilişsel ve destekleyici faktörleri içeren bir ölçektir. ${ }^{23}$

Türkiye'de hastaların insülin tedavisine ilişkin tutum ve inançlarını değerlendiren herhangi bir geçerli araç mevcut değildir. Hastaların tedaviye yönelik psikolojik dirençlerini ortaya çıkarabilmek ve tedaviye olan yanıtlarını daha olumlu hale getirmek için bu ölçek seçilmiştir. Çalışma PID Ölçeğini Türk toplumuna uyarlamak amacıyla yapıldı. Bu çalışma ile diyabetli hastalarda insülin tedavisine olan psikolojik direncin siklığının belirlenmesi ve tedaviye başlanmadan önce hastaların hazır oluşlarının değerlendirilmesi sağlanmış olacaktır.

\section{YÖNTEM}

\subsection{Araştırmanın Tipi}

$\mathrm{Bu}$ araştırma, tip 2 diyabetli hastalarda PID Ölçeğinin geçerlilik-güvenirliğini yapmak amacıyla metodolojik olarak yapıldı.

\subsection{Araştırmanın Yeri}

Araştırma, Malatya Eğitim ve Araştırma Hastanesinin dahili ve endokrin kliniklerinde yatan tip 2 diyabet tanısı alan hastalarla yapıldı.

\subsection{Araştırmanın Evren ve Örneklemi}

Evreni çalışmanın yapıldığı tarihlerde Malatya Eğitim ve Araştırma Hastanesinin dahili ve endokrin kliniklerinde yatan diyabet tanısı alan tüm hastalar oluşturdu. Ölçek çalışmalarında örneklem hacminin belirlenmesinde, ölçek madde sayısının 5-10 katı sayıda örnekleme ulaşılması önerilmektedir. ${ }^{24}$ Psikolojik İnsülin Direnci Ölçeği 18 maddeden oluştuğundan dolayı en az 180 kişiye ulaşılması hedeflendi. Örneklem büyüklüğünün belirlenmesinde ölçek madde sayısının 10 katından fazlası alınarak toplamda 201 birey ile araştırma tamamlandı. Araştırmadaki örneklem büyüklüğü 
faktör analizi yapmak için yeterlidir. Araştırmaya, hiç insülin kullanmamış tip 2 diyabet tanısı almış ve sözel iletişim kurulabilen hastalar dahil edildi.

\subsubsection{Veri Toplama Araçları}

Verilerin toplanmasında araştırmacılar tarafından hazırlanan diyabetli hastaları tanıtıcı anket formu ve PİD ölçeği kullanıldı.

\subsubsection{Tanitıcı Anket Formu}

Araştırmacılar tarafindan literatür doğrultusunda ${ }^{22,23,26}$ oluşturulan form toplamda 7 sorudan oluşmaktadır (yaş, cinsiyet, eğitim düzeyi, diyabet süresi, sağlık düzeyini algılama, diyabet eğitimi alma, beden kütle indeksi).

\subsubsection{Psikolojik İnsülin Direnci Ölçeği (Psychological Insulin Resistance Scale)}

Ölçek, Song ve arkadaşları tarafından 2016 yılında geliştirilmiştir. 5'li Likert tipinde (1:kesinlikle katılıyorum, 2:katılıyorum, 3:kararsızım, 4:katılmıyorum, 5:kesinlikle katılmıyorum) olan ölçek 18 maddeden ve 2 alt boyuttan (Destekleyici faktör ve Psiko-bilişsel/fiziksel faktör) oluşmaktadır. Ölçek toplam puanı 18-90 arasında değişmektedir. Ölçekten alınan yüksek puan psikolojik olarak insülin kullanımına karşı hasta direncinin fazla olduğunu göstermektedir. Orijinal ölçeğin toplam varyansının \%41,8, Cronbach's alfa katsayısının ise 0,91 olduğu belirlenmiştir. ${ }^{23}$ Destekleyici faktör alt boyutunun Cronbach's alfa katsayısı 0,75, psiko-bilişsel alt boyutunun Cronbach's alfa katsayısı 0,90 olarak saptanmıştır. ${ }^{23} \mathrm{Bu}$ araştırmada yapılan Türkçe geçerlik ve güvenirlik analizi sonucu ölçek 12 maddeden ve 3 alt boyuttan (destekleyici, psiko-bilişsel, fiziksel faktörler) oluşmaktadır. Cronbach alfa katsayısı 0,82 olarak belirlenmiştir. Destekleyici faktör alt boyutunun Cronbach alfa katsayıs1 0,75, Psikobilişsel alt boyutunun Cronbach alfa katsayısı 0,72, Fiziksel alt boyutunun Cronbach alfa katsayıs1 0,84 bulunmuştur. Veriler hastalarla yüz yüze görüşme yöntemiyle topland1.

\subsubsection{Dil Geçerliliği}

Ölçeklerin başka dildeki geçerlik çalışması, çevrilen dildeki kültürü yansıtması bakımından büyük önem taşımaktadır. Ölçeğin orjinali Kore dilindedir. Ancak ölçek maddeleri İngilizce dilinde orijinal makalede yer almaktadır. Ölçek ilk olarak Kore dilinden Türkçeye çevrilmiştir. Kore dilinde yazılan makalede yer alan İngilizce olan ölçek maddeleri üç uzman tarafindan birbirlerinden bağımsız olarak İngilizceden Türkçeye çevrilmiştir. Araştırmacılar ve Türk Dili uzmanı tarafından çevirinin Türkçe uygunluğu ve anlaşılırlığı değerlendirilmiştir. Ölçeğin uygun ve anlaşılır olması sağlandıktan sonra, Türkçe versiyonu oluşturulmuştur.

\subsection{Araştırma Verilerinin Analizi}

Araştırmanın verilerinin istatistiksel analizi SPSS 22.0 (Statistical Package for Social Science) programı kullanılarak değerlendirildi. Tanımlayıcı verilerin analizinde sayı, yüzde ve ortalama kullanıldı. Ölçeğin yapı geçerliliği açımlayıcı faktör analizi ile değerlendirildi. Faktör analizi yapılmadan önce, ölçeğin örneklem büyüklüğünü ve ölçek maddeleri arasındaki korelasyonun uygunluğunu test etmek amaciyla Kaiser-MeyerOlkin (KMO) ve Bartlett's testleri yapıldı. KMO değerinin 0.50-0.60 arasında olması kötü, 0.60 0.70 arasinda zayıf, $0.70-0.80$ arasinda orta, 0.80 0.90 arası iyi, 0.90 ve üzerinde olması ise örneklemin çok iyi olduğu ifade edilmektedir. ${ }^{25,27}$ Ölçeğin iç tutarlığını değerlendirmek için Cronbach alfa güvenirlik katsayısı ve madde toplam korelasyonu kullanıldı.

Tablo 1. Geçerlik-Güvenirlik Çalışması Veri Analizi

\begin{tabular}{|c|c|}
\hline \multicolumn{2}{|c|}{ Geçerlik-Güvenirlik Çalıșması } \\
\hline \multicolumn{2}{|c|}{$\begin{array}{l}\text { Geçerlik } \\
\text { Çalışması }\end{array}$} \\
\hline Dil geçerliği & Uzman görüşü \\
\hline Yapı geçerliği & $\begin{array}{l}\text { Açıklayıcı faktör analizi, Kaiser- } \\
\text { Meyer-Olkin analizi ve Barlett } \\
\text { Sphericity testleri }\end{array}$ \\
\hline $\begin{array}{l}\text { Güvenirlik } \\
\text { çalışması }\end{array}$ & \\
\hline Ölçek iç tutarlığ 1 & $\begin{array}{l}\text { Madde Analizi, Cronbach Alfa } \\
\text { Katsayis1, Spearman-Brown, } \\
\text { Guttman, Split Half } \text { Methods, } \\
\text { Spearman-Brown } \\
\text { Katsayis1 }\end{array}$ \\
\hline
\end{tabular}

\subsection{Araștırmanın Etik İlkeleri}

Ölçeğin Türkçe geçerlik ve güvenirliğinin yapılabilmesi için Song'dan mail yolu ile izin alındı. Araştırma için İnönü Üniversitesi Bilimsel Araştırma ve Yayın Etiği Kurulu'ndan (Sağlık Bilimleri Girişimsel olmayan klinik araştırmalar etik kurulu) Etik kurul izni alındı (Karar sayısı: 2020/187). Araştırma, Helsinki Bildirgesi Prensiplerine uygun olarak yapıld1.

\section{BULGULAR}

\subsection{Tanımlayıcı Özellikler}

Hastaların \%54,2'sinin kadın, \%50,2'sinin ilköğretim mezunu, \%45,8'inin 11 y1l ve üzeri diyabet hastası olduğu, \%60,2'sinin sağlığını orta düzey olarak değerlendirdiği, \%65,7'sinin diyabet eğitimi aldığ 1 , yaş ortalamalarının $57,05 \pm 14,7$, 
beden kütle indeksleri ortalamalarının ise $28,18 \pm 6,37$ olduğu saptandı (Tablo 2).

Tablo 2. Hastaların sosyo-demografik özellikleri

\begin{tabular}{lll}
\hline Özellik & S & \% \\
\hline Cinsiyet & 109 & 54,2 \\
Kadın & 92 & 45,8 \\
Erkek & & \\
Eğitim düzeyi & 51 & 25,4 \\
Okuryazar değil & 101 & 50,2 \\
İlkögretim & 33 & 16,4 \\
Ortaöğretim & 16 & 8,0 \\
Üniversite ve üzeri & & \\
Diyabet süresi & 70 & 34,8 \\
1-5 yıl & 39 & 19,4 \\
6-10 yıl & 92 & 45,8 \\
11 yıl ve üzeri & & \\
Sağlık düzeyini algılama & 19 & 9,5 \\
İyi & 121 & 60,2 \\
Orta & 61 & 30,3 \\
Kötü & & \\
Diyabet eğitimi alma & 132 & 65,7 \\
Evet & 69 & 34,3 \\
Hayır & $\mathbf{X} \pm \mathbf{S S}$ & \\
\hline & $57,05 \pm 14,7$ & \\
Yaş & $28,18 \pm 6,37$ \\
Beden Kütle İndeksi $\left(\mathrm{kg} / \mathrm{m}^{2}\right)$ &
\end{tabular}

\subsection{Yapı Geçerliliği}

KMO değeri 0,77 ve Bartlett's testi $X^{2}=877,833 p=$ 0,000 bulundu. Ölçeğin faktör analizine uygunluğu belirlendikten sonra (KMO VE Bartlett's test uygunluğu ile) varimax ratosyonlu, temel bileşenler analiz yöntemi ile ölçek boyutları belirlendi. Faktör yükü 0,40 altında olan altı madde (1.Yaşam boyu insülin tedavisi almak korkutucudur, 2. İnsülinin yan etkilerinden korkuyorum (hipoglisemi, kilo alma gibi), 4. İnsülin tedavisini son çare olarak görüyorum, 5. İnsülin tedavisi almak kendimi yönetmede (sağlıklı beslenme, spor yapmak vs.) başarısız olduğum anlamına gelir, 13. İnsülin tedavileri çok ağır hastalar içindir, 15. İnsülin tedavisi, ekonomik bir yük olabilir) ölçekten çıkarıldı. Bu maddeler çıkarıldıktan sonra öz değeri $\geq 1$ olan üç alt boyutta topland. Toplam varyans $\% 60,4$ bulundu. Sonuçta 12 madde, 3 faktörlü ve her bir madde $\geq 0,50$ faktör yükü olan ve binişik madde bulunmayan, Türk kültürüne uyarlanan ölçek meydana geldi.

\subsection{Doğrulayıcı Faktör Analizi}

Ölçek geliştirmelerde açımlayıcı faktör analizini, doğrulayıc1 faktör analizin takip etmesi önerilmektedir. ${ }^{27,28}$ CFA pek çok değişkenden oluşmuş faktörlerin gerçek verilerle ne düzeyde uyum gösterdiğini değerlendirmeyi amaçlayan analiz türüdür. Pek çok sayıda uyum indeksi kullanılır. $\mathrm{Bu}$ araştırmada sık kullanılan indekslerden $\mathrm{CMIN}\left(\mathrm{X}^{2}\right) / \mathrm{DF}$, SRMR, GFI, AGFI, NFI, CFI, RMSEA, AMOS programiyla hesaplanmıştır. $^{28}$ GFI, AGFI, NFI, CFI'nin 1 değerine yaklaşması, RMSEA'da 0,05 den küçük olmas1, mükemmel uyumu ifade etmektedir. ${ }^{27,28}$ Araştırma bulguları doğrulayıcı analizi bulgularının uyumlu olduğunu göstermektedir.

Tablo 3. Ölçek maddelerinin doğrulayıcı faktör analizi

\begin{tabular}{llllllll}
\hline & CMIN $\left(\mathbf{X}^{2}\right) / D F$ & SRMR & GFI & AGFI & NFI & CFI & RMSEA \\
\hline Optimal model & $<3$ & $\leq 0,088$ & $\geq 0,90$ & $\geq 0,90$ & $\geq 0,90$ & $\geq 0,90$ & $<0,06$ \\
Yapılandırılmış & 1,511 & 0,086 & 0,946 & 0,911 & 0,921 & 0,971 & 0,051 \\
model & & & & & & & \\
\hline
\end{tabular}

\section{4 İç Tutarlılık}

Ölçek maddeleri diyabetli 201 bireye uygulandı. Ölçeğin son hali 12 maddeden oluştu. Ölçeğin iç tutarlılığını belirlemede Cronbach alpha, madde toplam korelasyonu, faktör analizi kullanıldı. Yapısal geçerliliği test etmek için kullanılan faktör analizinde öncelikle ölçeğin bu analizi yapmak için uygun olup olmadığı Barlett ve Kaiser Meyer Olkin (KMO) testleri ile belirlendi. $\mathrm{Bu}$ ölçeğin madde korelasyon en düşük değeri 0,401, KMO testi 0,77 , $\mathrm{p}=0,001$ olarak belirlendi.
Tablo 4'de ölçeğinin geçerlik güvenirlik analiz sonuçları verildi. Ölçek madde ortalamalarının 2,35-3,59, toplam madde korelasyon 0,401-0,539, faktör yükü 0,549-0,905, arasında olduğu belirlendi. Ölçek ortalamasının 36,03 , toplam varyans1 $\% 60,4$ olarak belirlendi. Spearman-Brown yarılama katsayısı 0,882 olarak saptanmıştır, yüksek iç tutarlılık olduğu belirlenmiştir.

Toplam katılımcı sayısının en yüksek ölçek puanına sahip olan \%27'lik dilimi (54 kişi) “üst grup”, en düşük ölçek puanına sahip olan \%27'lik 
dilimi (54 kişi) ise "alt grup" olarak tanımlamıştır. Tablo 5 deki bulgulara göre, üst ile alt grup puan ortalamaları arasındaki fark istatistiksel olarak anlamlıdır $(\mathrm{t}=28,309 ; \mathrm{p}<0,05)$. Dolayısıyla ölçeğin ayırt edicilik özelliğine ve iç tutarlılığa sahip olduğu söylenebilir.

Tablo 4. Ölçek maddelerinin toplam madde korelasyon ve faktör yükleri

\begin{tabular}{|c|c|c|c|c|c|}
\hline Ölçek maddeleri & $\operatorname{Ort}(\mathbf{S S}) *$ & $\begin{array}{l}\text { Toplam } \\
\text { madde } \\
\text { korelasyon }\end{array}$ & $\begin{array}{l}\text { Faktör } \\
\text { yükü }\end{array}$ & Alfa & Varyans \\
\hline Destekleyici faktör & & & & 0,757 & 21,296 \\
\hline $\begin{array}{l}\text { 14.Toplum içinde insülin enjeksiyonu } \\
\text { yapmak utanç verici olabilir. }\end{array}$ & $2,87(1,51)$ & 0,478 & 0,549 & & \\
\hline 16. Ailem için üzülüyorum & $2,35(1,69)$ & 0,401 & 0,804 & & \\
\hline $\begin{array}{l}\text { 17. Ailem konusunda karmaşık duygulara } \\
\text { sahibim (üzgün ve haksızlığa uğramış gibi) }\end{array}$ & $2,55(1,64)$ & 0,492 & 0,873 & & \\
\hline $\begin{array}{l}\text { 18. Ailemde işe yaramaz bir fert (birey) } \\
\text { olduğumu düşünüyorum }\end{array}$ & $3,47(1,63)$ & 0,513 & 0,650 & & \\
\hline Psiko-bilişsel faktör & & & & $\mathbf{0 , 7 2 9}$ & 19,609 \\
\hline $\begin{array}{l}\text { 6. Kendime insülin enjekte etme konusunda } \\
\text { güvenmiyorum }\end{array}$ & $3,10(1,54)$ & 0,492 & 0,786 & & \\
\hline $\begin{array}{l}\text { 7. İnsülin tedavisi karmaşık ve rahatsız edici } \\
\text { bir tedavidir }\end{array}$ & $2,84(1,46)$ & 0,468 & 0,647 & & \\
\hline $\begin{array}{l}\text { 10. İnsülin tedavisi hakkında bilgim } \\
\text { yetersiz, }\end{array}$ & $3,40(1,30)$ & 0,412 & 0,647 & & \\
\hline $\begin{array}{l}\text { 11. Tedavide başkalarının yardımına ihtiyaç } \\
\text { duyabilirim. }\end{array}$ & $2,59(1,59)$ & 0,539 & 0,490 & & \\
\hline $\begin{array}{l}\text { 12. Gözümdeki bozukluk (Yetersiz görme) } \\
\text { nedeniyle dozu ayarlamakta zorlanıyorum. }\end{array}$ & $2,62(1,48)$ & 0,471 & 0,611 & & \\
\hline Fiziksel Faktör & & & & $\mathbf{0 , 8 4 7}$ & $\mathbf{1 9 , 5 8 4}$ \\
\hline 3. İğnelerden korkuyorum. & $3,59(1,62)$ & 0,525 & 0,861 & & \\
\hline 8. İğne ağrısından korkuyorum & $3,51(1,63)$ & 0,534 & 0,905 & & \\
\hline $\begin{array}{l}\text { 9. İğnenin ciltte oluşturduğu morluklardan } \\
\text { korkuyorum. }\end{array}$ & $3,10(1,58)$ & 0,464 & 0,764 & & \\
\hline Toplam & $36,03(13,08)$ & & & $\mathbf{0 , 8 2 7}$ & 60,489 \\
\hline
\end{tabular}

Tablo 5: Araştırma verilerinin ikiye bölünmüş yöntem ile gösterimi

\begin{tabular}{llllll}
\hline Gruplar & N & Ort. & SS & t & p \\
\hline Üst Grup & 54 & 49,44 & 5,09 & & \multirow{2}{*}{0,309} \\
Alt Grup & 54 & 22,25 & 4,86 & & $\mathbf{0 , 0 0 1}$ \\
\hline
\end{tabular}

\section{TARTIŞMA}

İnsülin tedavisi, glisemik kontrolü sağlamada etkili olmasına rağmen genellikle tip 2 diyabetli bireylerde PİD'e bağlı olarak gecikmektedir. PİD' in oluşmasındaki en büyük etken hastaların diyabet ve insülin tedavisi hakkındaki bilgi eksikliğidir. ${ }^{26}$ Araştırma, tip 2 diyabetli hastalarda insülin tedavisine ilişkin tutum ve inançları değerlendiren PID ölçeğinin geçerlik ve güvenirliğini değerlendirmektedir. Araştırmada Song ve ark.
(2016) tarafından geliştirilen PİD ölçeğinin Türkçe versiyonunun dilbilimsel doğrulaması başarıyla gerçekleştirildi. Sonuçlar elde edilen dil versiyonunun kültürel olarak ilgili ve hedef popülasyon için kabul edilebilir olduğunu göstermektedir.

PİD ölçeğinin 201 hastada tamamlanan psikometrik ölçümleri üç bileşenli, kolayca uygulanabilen ve yorumlanabilen bir yapı gösterdi. $\mathrm{Bu}$ bileşenlerden ilki olan destekleyici faktörler 
insülin kullanımını engelleyebilecek tedavide yardıma ihtiyaç duyma, yetersiz görme nedeniyle doz ayarında zorlanma, enjeksiyona dair utanma duygusu ve aileye yönelik kaygıları içeren maddelerden oluşuyordu. Bu boyuttaki en yüksek faktör yükünü 'ailem konusunda karmaşık duygulara sahibim (üzgün ve haksızlığa uğramış gibi)' ifadesini içeren 17. madde gösterdi $(0,873)$. Song ve ark. (2016) da bu maddenin faktör yükünü $(0,84)$ en yüksek bulmuştur. ${ }^{23}$

İkinci boyut olan psiko-bilişsel faktör ise enjeksiyon yapma konusunda güven eksikliği, insülin tedavisinin karmaşık ve rahatsız edici bulunması ve insülin tedavisi hakkındaki bilgi eksikliği ile ilgili maddelerden oluşuyordu. Kendime insülin enjekte etme konusunda güvenmiyorum $(0,786)$ maddesi en yüksek faktör yüküne sahipti. Üçüncü boyut olan fiziksel faktör ise iğnenin kendisinden korkma, iğnenin meydana getirdiği ağrı ve morluklardan korkma, bu boyuttaki en yüksek faktör yükünü 'iğne ağrısından korkuyorum' ifadesini içeren 8. madde gösterdi $(0,905)$. Farklı olarak Song ve ark. (2016) en yüksek faktör yükünü 'iğnenin kendisinden korkuyorum' ifadesini içeren 3. madde $(0,78)$ olarak belirlemiştir. ${ }^{23} \mathrm{Hem}$ bu araştırmaya hem de Song ve ark.'nın (2016) çalışmasına ait bulgular farklı kültürlerde de olsa enjeksiyona dair korkuların ve aile ile ilişkili kaygıların insülin kullanımı önündeki psikolojik engellerin başında geldiğine işaret etmektedir.

PİD Ölçeğinin destekleyici ve psikolojik-bilişsel boyutları, insülin kullanımının önündeki engelleri araştırmak için geliştirilen, farklı kültürlerde ve Türk toplumunda geçerliği bulunan İnsülin Tedavi Engelleri Anketini (BITQ) de destekler niteliktedir. $\mathrm{Bu}$ anket enjeksiyon korkusu ve kendi kendine test etme, pozitif insülinle ilgili sonuçlarla ilgili beklentiler, insülin tedavisinden beklenen zorluk, insülin enjeksiyonları ile damgalanma ve hipoglisemi korkusu gibi durumları değerlendirmektedir. ${ }^{29,30}$ BITQ Türk toplumuna uyarlanmış sonuçları enjeksiyon korkusu ve enjeksiyona ilişkin damgalanma boyutlarında yer alan maddelerin yüksek faktör yüküne sahip olduğunu göstermiştir. ${ }^{30}$ BITQ ölçek geliştirme çalışması ve insülin kullanımının önündeki engelleri araştıran diğer çalışmalarda destekleyici ve psikolojik-bilişsel faktörleri destekleyen sonuçlar olduğu ve bu durumun insülin kullanımı önündeki önemli engellerden olduğu görülmüştür. ${ }^{4,5,9,12,29,30} \mathrm{Bu}$ nedenle bu ölçek insülin kullanımın önündeki psikolojik faktörleri detaylı bir şekilde değerlendirebilmesi ve Türk toplumuna uygun olması yönüyle önemlidir.

Araştırmada örneklemin faktör analizi için uygunluğunu test etmek amaciyla KMO test sonucuna bakılmıştır. KMO değerinin 0,77 olduğu belirlenmiştir. Araştırmada ölçeğin Bartlett's test sonucunun $\left(\mathrm{X}^{2}=877,833, \mathrm{p}=0,000\right)$ anlamlı olduğu ve verilerin normal dağılım gösterdiği saptandı. Bu sonuçlar doğrultusunda araştırmanın örneklem büyüklüğünün faktör analizi için yeterli büyüklükte ve güvenirlikte olduğu sonucuna ulaşıldı. Açımlayıcı faktör analizi sonucunda öz değeri 1'in üzerinde üç faktörlü 12 maddelik bir yapı elde edilmiş ve açıklanan varyansının \% 60,48 olduğu belirlenmiştir. Orijinal ölçekte fiziksel ile psikobilişsel faktörün tek bir alt boyutta olduğu görülmektedir. ${ }^{23} \mathrm{Bu}$ ölçek uyarlanmasında yüksek düzeyde toplam varyans elde edebilmek için, ölçek üç alt boyutta toplanmış olup fiziksel ile psikobilişsel boyut maddeleri ayrılmıştır. Orijinal ölçeğin 2 faktörlü, 18 madde ve varyansın $\% 41,8$ olduğu bulunmuştur. ${ }^{21,23}$

Araştırmada, toplam ölçek Cronbach alfa katsayısı 0,82, alt ölçeklerin Cronbach alfa değerlerinin sirasiyla $0,75, \quad 0,72, \quad 0,84$ olduğu saptanmıştır. Orijinal ölçekte Cronbach alfa değeri 0,91 olarak belirlenmiştir. ${ }^{23}$ Türkçe ölçeğin orijinal ölçekle karşılaştırıldığında, orijinal ölçeğe benzer ve oldukça yüksek derecede güvenilir olduğu söylenebilir.

\section{Araştırmanın Sınırlılıkları}

Araştırmanın olası bir sınırlaması PİD ölçeğinde test-tekrar test güvenilirliğinin yapılmamış olmasıdır. Ayrıca ölçeğin sadece tip 2 diyabetli hastalara uygulanmış olmasının, bu ölçeğin tip 1 diyabetli hastalar için kullanımını sınırlandırdığ düşünülmektedir. $\mathrm{Bu}$ nedenle ileri araştırmalarda PID ölçeğinin test-tekrar test analizlerinin yapılması ve tip 1 diyabetli hastalara uyarlanması faydalı olacaktır.

\section{SONUC}

Mevcut araştırma sonuçlarına göre PİD ölçeğinin Türk toplumu için geçerli ve güvenilir bir ölçme aracı olduğu belirlendi. Ölçeğin tip 2 diyabet hastalarında PID varlığını belirlemede kullanılması ve diyabet tedavisinde psikolojik açıdan oluşabilecek engellerin de sağlık profesyonelleri tarafından göz önünde bulundurularak tedavinin hasta açısından tüm yönlü (fiziksel, psikolojik, sosyal ) ele alınması önerilmektedir.

\section{KAYNAKLAR:}

1. Care D, Suppl SS. Pharmacologic approaches to glycemic treatment: Standards of medical care in diabetesd 2019. Diabetes Care. 2019; 42(January):90-102. 
2. Attitudes D, Polonsky W. Psychological Insulin Resistance. 1991, 92014, 241-244.

3. Brod M., Kongsø JH, Lessard S, Christensen TL. Psychological insulin resistance: patient beliefs and implications for diabetes management. 2009. Quality of Life Research, $18(1), 23-32$.

4. Petrak F, Herpertz S, Stridde E, Pfützner A. Psychological insulin resistance in type 2 diabetes patients regarding oral antidiabetes treatment, subcutaneous insulin injections, or inhaled insulin. Diabetes Technology and Therapeutics. 2013, 15(8), 703-11.

5. Yu JH, Kim HY, Kim SR, Ko E, Jin HY. Factors influencing psychological insulin resistance in type 2 diabetes patients. International journal of nursing practice. 2019, 25(3), e12733.

6. Song $\mathrm{Y}, \mathrm{Ku}$ BJ, Cho J, Jun Y, Kim B, Nam S. The prevalence of insulin refusal and psychological insulin resistance among Korean patients with type 2 diabetes mellitus. Annals of Translational Medicine. 2019, 7(23), 760.

7. Woudenberg YJC, Lucas C, Latour C, Scholte Op Reimer WJM. Acceptance of insulin therapy: A long shot? Psychological insulin resistance in primary care. Diabetic Medicine. 2012, 29(6), 796-802.

8. Meece J. Dispelling myths and removing barriers about insulin in type 2 diabetes. Diabetes Educator. 2006, 32(1 SUPPL.), 9-18.

9. Larkin ME, Capasso VA, Chen CL, Mahoney EK, Hazard B, Cagliero E, Nathan DM. Measuring psychological insulin resistance: barriers to insulin use. The Diabetes Educator. 2008, 34(3), 511-7.

10. Polonsky William H, Hajos TRS, Dain MP, Snoek FJ. Are patients with type 2 diabetes reluctant to start insulin therapy? An examination of the scope and underpinnings of psychological insulin resistance in a large, international population. Current Medical Research and Opinion. 2011, 27(6), 1169-74.

11. Polonsky WH, Jackson RA. What's So Tough About Taking Insulin? Addressing the Problem of Psychological Insulin Resistance in Type 2 Diabetes. Clinical Diabetes. 2004, 22(3), 14750.

12. Snoek FJ, Skovlund SE, Pouwer F. Development and validation of the insulin treatment appraisal scale (ITAS) in patients with type 2 diabetes. Health and Quality of Life Outcomes. 2007, 5, 1-7.

13. Brod M, Kongsø JH, Lessard S, Christensen TL. Psychological insulin resistance: Patient beliefs and implications for diabetes management. Quality of Life Research. 2009, 18(1), 23-32.

14. Nam S, Nam S, Song Y. Role of Self-Efficacy in the Relationship Between Patient-Provider Relationships and Psychological Insulin Resistance Among Patients with Type 2 Diabetes. Journal of Contemporary Diabetes Research. 2015, 1(1), 1-15.

15. Ng CJ, Lai PSM, Lee YK, Azmi SA, Teo CH. Barriers and facilitators to starting insulin in patients with type 2 diabetes: A systematic review. International Journal of Clinical Practice, 2015, 69(10), 1050-70.

16. Nicolucci A, Kovacs Burns K, Holt RIG, Comaschi M, Hermanns N, Ishii H, Kokoszka A, Pouwer F, Skovlund SE, Stuckey H, Tarkun I, Vallis M, Wens J, Peyrot M. Diabetes attitudes, wishes and needs second study (DAWN2 ${ }^{\mathrm{TM}}$ ): Cross-national benchmarking of diabetes-related psychosocial outcomes for people with diabetes. Diabetic Medicine. 2013, 30(7), 767-77.

17. Saleem A, Masood I, Khan TM. Insulin perception among insulin-naïve type- 2 diabetes mellitus patients in Pakistan. Cogent Medicine. 2016, 3(1).

18. Wong S, Lee J, Ko Y, Chong MF, Lam CK, Tang WE. Perceptions of insulin therapy amongst Asian patients with diabetes in Singapore. Diabetic Medicine. 2011, 28(2), 206-11.

19. İnkaya BV, Karadağ E. Diyabetli bireyler ve onlara bakım veren hemşirelerin hastalık özyönetim stratejilerine bakışı: Kalitatif bir çalışma. Koç Üniversitesi Hemşirelikte Eğitim ve Araştırma Dergisi (HEAD). 2017, 14(1), 31 7.

20. Bahrmann A, Abel A, Zeyfang A, Petrak F, Kubiak T, Hummel J, Oster P, Bahrmann P. Psychological insulin resistance in geriatric patients with diabetes mellitus. Patient Education and Counseling. 2014, 94(3), 41722.

21. Kim B, Song Y, Kim JI. Psychological insulin resistance and low self-efficacy as barriers to diabetes self-care management in patients with 
type 2 diabetes. Korean Journal of Adult Nursing. 2019, 31(1), 61-7.

22. Lim A, Song Y. The role of psychological insulin resistance in diabetes self-care management. Nursing Open. 2020, February, $1-8$.

23. Song Y, Jeon Y, Cho J, Kim B. Development of a psychological insulin resistance scale for Korean patients with diabetes. Journal of Korean Academy of Nursing. 2016, 46(6), 813-23.

24. Coşkun S, Bebiş H. Adolesanlarda e-sağlık okuryazarlığı ölçeği: Türkçe geçerlik ve güvenirlik çalışması. Gülhane Tıp Derg. 2015, 57, 378-84.

25. Gümüş H, Özgül SA. Rekreasyon alanı kullanımına ilişkin katılım engelleri ve tercih etkenleri ölçeklerinin geliştirilmesi. Journal of Human Sciences. 2017, 14(1), 865-82.

26. Allen NA, Zagarins SE, Feinberg RG, Welch $\mathrm{G}$. Treating psychological insulin resistance in type 2 diabetes. Journal of Clinical \& Translational Endocrinology. 2017, 7, 1-6

27. Kartal M, Bardakçı S. SPSS ve AMOS Uygulamalı Örneklerle Güvenirlik ve Geçerlik Analizleri. Ankara: Akademisyen Yayınevi. 2018

28. Karagöz Y. SPSS 23 ve AMOS 23 uygulamalı istatistiksel analizler. Nobel Akademik Yayıncılık. 2016.

29. Petrak F, Stridde E, Leverkus F, Crispin AA, Forst T, Pfützner A. Development and validation of a new measure to evaluate psychological resistance to insulin treatment. Diabetes Care. 2007,30(9) 2199-2204.

30. Saritas SC, Erci B, Sahin I, Timocin E. Validity study of the Turkish version of the barriers to insulin treatment questionnaire. International Journal of Diabetes in Developing Countries. 2019, 39 (2) 247-253. 